\title{
COL6A3 promotes cellular malignancy of osteosarcoma by activating the PI3K/AKT pathway
}

1. Department of Nursing, Binzhou Vocational College, № 919, Huang He Shi Er Road, Binzhou, Shandong,256603 China 2. Department of Orthopedics of Binzhou People's Hospital, № 515, Huang He qi Road, Binzhou, Shandong,256610 China

\section{SUMMARY}

OBJECTIVE: In this study, we aimed to investigate the role of COL6A3 on cell motility and the PI3K/AKT signaling pathway in osteosarcoma. METHODS: The relative expression of COL6A3 was achieved from a GEO dataset in osteosarcoma tissue. siRNA technology was applied to decrease the COL6A3 expression in cells, and cell counting kit-8 (CCK-8) assay and colony formation analysis were used to examine the cell proliferation potential. Knockdown COL6A3 made the proliferation and colony formation abilities worse than the COL6A3 without interference. Likewise, in contrast to the si-con group, cell invasion and migration were inhibited in the si-COL6A3 group. Moreover, the western blot results suggested that the PI3K/AKT signaling pathway was manipulated by measuring the protein expression of the PI3K/AKT pathway-related markers, due to the COL6A3 inhibition.

CONCLUSION: COL6A3 plays a crucial role in modulating various aspects of the progression of osteosarcoma, which would provide a potentially effective treatment for osteosarcoma.

KEYWORDS: Osteosarcoma. Neoplasms, bone tissue. Molecular targeted therapy. Collagen type VI.

\section{INTRODUCTION}

Osteosarcoma is a prevalent and aggressive tumor in the bones that has received widespread attention because of its particular features ${ }^{\mathbf{1}}$. Up to now, radical surgery, chemotherapy, and radiotherapy are the most commonly used treatments in osteosarcoma, but the cure rate is not significant ${ }^{2}$. It is well-known that targeted therapy is a major and effective modality for cancer, and numerous genes have been proved to be associated with the progression of tumors ${ }^{3,4}$. Hence, novel biomarkers are urgently needed for the diagnosis and treatment of osteosarcoma.

Collagen VI (COL6) is a extracellular-matrix protein, which is related to the basement membrane and made up of three chains: alpha 1, alpha 2 , and alpha $3^{5}$. Previous reports have illustrated that COL6 is involved in muscle regularity and cell membrane 
integrity $^{6}$. There is evidence that the loss of COL6 can cause serious Bethlem myopathy and Ullrich congenital muscular dystrophy?.

However, there is no literature to interpret the functional characteristics of COL6A3 in osteosarcoma. The purpose of the study was to investigate the role of COL6A3 on cell motility and the PI3K/AKT signaling pathway in osteosarcoma.

\section{ETHODSCELL LINES AND CULTURE CONDITION}

Human osteosarcoma cell lines (U2OS, HOS, and MG-63) and normal cell lines hFOB1.19 were purchased from the cell bank of the Chinese Academy of Sciences (Shanghai, China), which were then incubated in RPMI-1640 medium. To maintain the normal viability of cells, fetal bovine serum (FBS; $10 \%$ ), penicillin $(100 \mathrm{U} / \mathrm{mL})$, and streptomycin $(100 \mathrm{U} / \mathrm{mL})$ were used. All the cells were stored at $37^{\circ} \mathrm{C}$ and $5 \% \mathrm{CO} 2$.

\section{TRANSFECTION}

To knockdown COL6A3, small interfering RNAs (siRNAs) including si-COL6A3 and si-con were designed by GenePharma (Shanghai, China). The sequences of two siRNAs are as follow: COL6A3 siRNA: 5'-GCTTTGCACATATTCGAGATT-3'; si-con: 5'AATTCTCCGAACGGTCACGT-3'. The si-con was used as a negative control. For transfection, cells were treated with siRNAs using Lipofectamine2000 per the manufacture protocol. After $24 \mathrm{~h}$ transfection, the knockdown efficiency of COL6A3 can be observed for further detection.

\section{Reverse transcription-quantitative} polymerase chain reaction ( $q P C R$ )

To detect the mRNA expression level of a specific gene, TRIzol solution (Invitrogen, Carlsbad, CA, USA) was used to isolate total RNA, and then qRT-PCR analysis was carried out. Then RNA was converted into cDNA using the Fast Quant RT Kit (TaKaRa, Otsu, Shiga, Japan). qPCR was performed with the Applied Biosystems 7500 Real-Time PCR System (Thermo Fisher Scientific, Inc., Waltham, MA, USA) and, in the meantime, SYBR Green Master Mix was also utilized as a dyeing probe. The reaction procedure was the following: pre-heated at $95^{\circ}$ for $5 \mathrm{~min}$, denatured at $95^{\circ} \mathrm{C}$ for $30 \mathrm{~s}$ and $60^{\circ}$ for $45 \mathrm{~s}$ with 40 cycles, $72^{\circ}$ for $30 \mathrm{~min}$. The forward primer of
COL6A3 was 5'-AACATCCTGGTCAGCTCTGC-3' and the reverse primer was 5'-TCCGGGATGAAGGAGATGGT-3'. In addition, the forward primer of GAPDH was 5'-TCCAAAATCAAGTGGGGCGA-3', and its reverse primer was 5'TGATGACCCTTTTGGCTCCC-3'. GAPDH was assessed as internal control and all detections were conducted three times. The $2^{-\Delta \Delta C T}$ method was used to examine relative expression.

\section{Western blotting}

Transfected cells for $24 \mathrm{~h}$ were placed on ice and lysed by RIPA reagent (Beyotime, Shanghai, China) supplemented with a protease inhibitor to extract proteins. Then, the isolated proteins were concentrated by the BCA method and boiled at $95^{\circ}$ for $5 \mathrm{~min}$. In the vertical electrophoresis tank, 20 $\mu \mathrm{g}$ protein was added into each well, separating by $12 \%$ SDS-PAGE at $110 \mathrm{v}$ for $1 \mathrm{~h}$ and transferred onto the PVDF membrane. Subsequently, the PVDF membrane was blocked using 5\% skim milk powder for $1 \mathrm{~h}$ and antibodies. Primary antibodies (1:1,000; Abcam, Cambridge, MA, USA) were used to incubate the membrane at $4^{\circ} \mathrm{C}$ overnight, and a secondary antibody (1:2,000; Abcam, Cambridge, MA, USA) at room temperature for $1 \mathrm{~h}$. Finally, ECL was added for development and the gray value of protein bands was scanned through the QUANTITY ONE software.

\section{Cell proliferation and colony formation assays}

Cell counting kit 8 (CCK-8) analysis and colony formation exploration were applied to evaluate the proliferative and clonal abilities. For the CCK- 8 assay, the single-cell suspensions generated by the transfected cells were seeded into a 96-well plate with a density of 1,000 cells per well, at $37^{\circ} \mathrm{C}$ for 0-72 h. Every 24 hours were considered as a detection time point and the cells should go through an additional culture $1.5 \mathrm{~h}$ after supplementing with $10 \mu \mathrm{L}$ CCK- 8 reagent. At last, the OD value was measured at $450 \mathrm{~nm}$ using a microplate reader. For colony formation exploration, transfected cells were inoculated in a $60 \mathrm{~mm}$-depth dish, which was pre-filled with $5 \mathrm{~mL}$ warm medium; the density was 400 cells/dish. The culture was completed when macroscopic clones appeared in the culture dish (about two weeks), fixed then stained by $4 \%$ paraformaldehyde and $0.1 \%$ crystal violet, respectively, for $30 \mathrm{~min}$. Finally, the clone was counted and captured under a microscope.

\section{Transwell assay}

Transwell assay was carried out to assess cell migration and invasion. Cells after $24 \mathrm{~h}$ transfection were 
turned into a cell suspension and put into the upper chamber. Meanwhile, the lower chamber was filled with $500 \mu \mathrm{L}$ complete medium. After waiting overnight, the residual cells on the surface of the upper chamber were wiped out and the chamber was washed using PBS for three times. The cells on the surface of the lower chamber were fixed using $4 \%$ paraformaldehyde, dyed via $0.1 \%$ crystal violet, and imaged through the microscope. Attentively, the upper chamber was pre-coated with Matrigel (BD Sciences, Franklin Lakes, NJ, USA) for invasion while migratory detection was not. Furthermore, the inoculated density was different: 5 , 000 cells for migration and $1 \times 10^{5}$ cells for invasion.

\section{Statistical analysis}

Based on the SPSS 22.0 statistics software (SPSS Inc., Chicago, IL, USA) and GraphPad Prism 5.0 (GraphPad Software, San Diego, CA, USA), all data were analyzed and described as mean \pm standard deviation (SD).
Differential analysis of the two groups was conducted with the student's t-test; the comparison of multiple groups was conducted by one-way ANOVA and Dunnett's post hoc test. The significance of this test was $p<0.05$.

\section{RESULTS}

COL6A3 was associated with metastasis of osteosarcoma

Initially, we collected two arrays from the GEO dataset to examine the expression level of COL6A3 in osteosarcoma tissues and discovered that the expression level of COL6A3 was significantly increased in both GSE16088 ( $\mathrm{P}=0.0324)$ involving 14 osteosarcoma cases and 3 normal cases and GSE49003 $(\mathrm{P}=0.0022)$ containing 6 non-metastasis cases and 6 metastasis cases. These findings indicate that the development of osteosarcoma was closely associated with the COL6A3

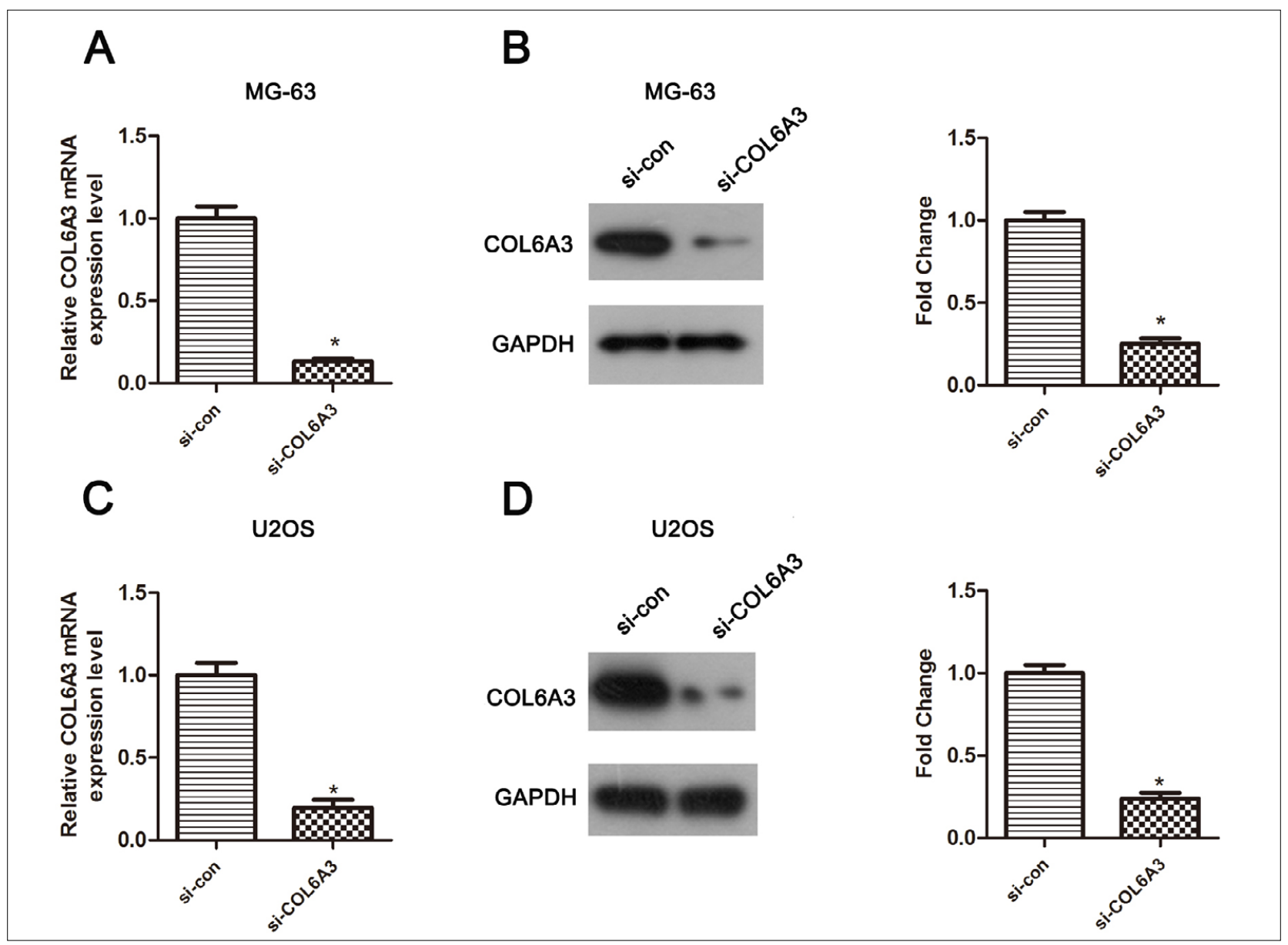

FIGURE 1. HIGH EXPRESSION OF COL6A3 WAS ASSOCIATED WITH METASTASIS IN OSTEOSARCOMA.

A) Relative expression of COL6A3 between normal tissue and osteosarcoma tissue, which was obtained from the GEO database, $P=0.0324$. B) Relative expression of COL6A3 between non-metastasis tissue and metastasis tissue from the GEO database, $P=0.0022$. C) The qRT-PCR analysis revealed a multiple expression tendency in three osteosarcoma cell lines (U2OS, HOS, and MG-63) and one in a normal cell line hFOB1.19, ${ }^{\star \star *} P<0.001$. 


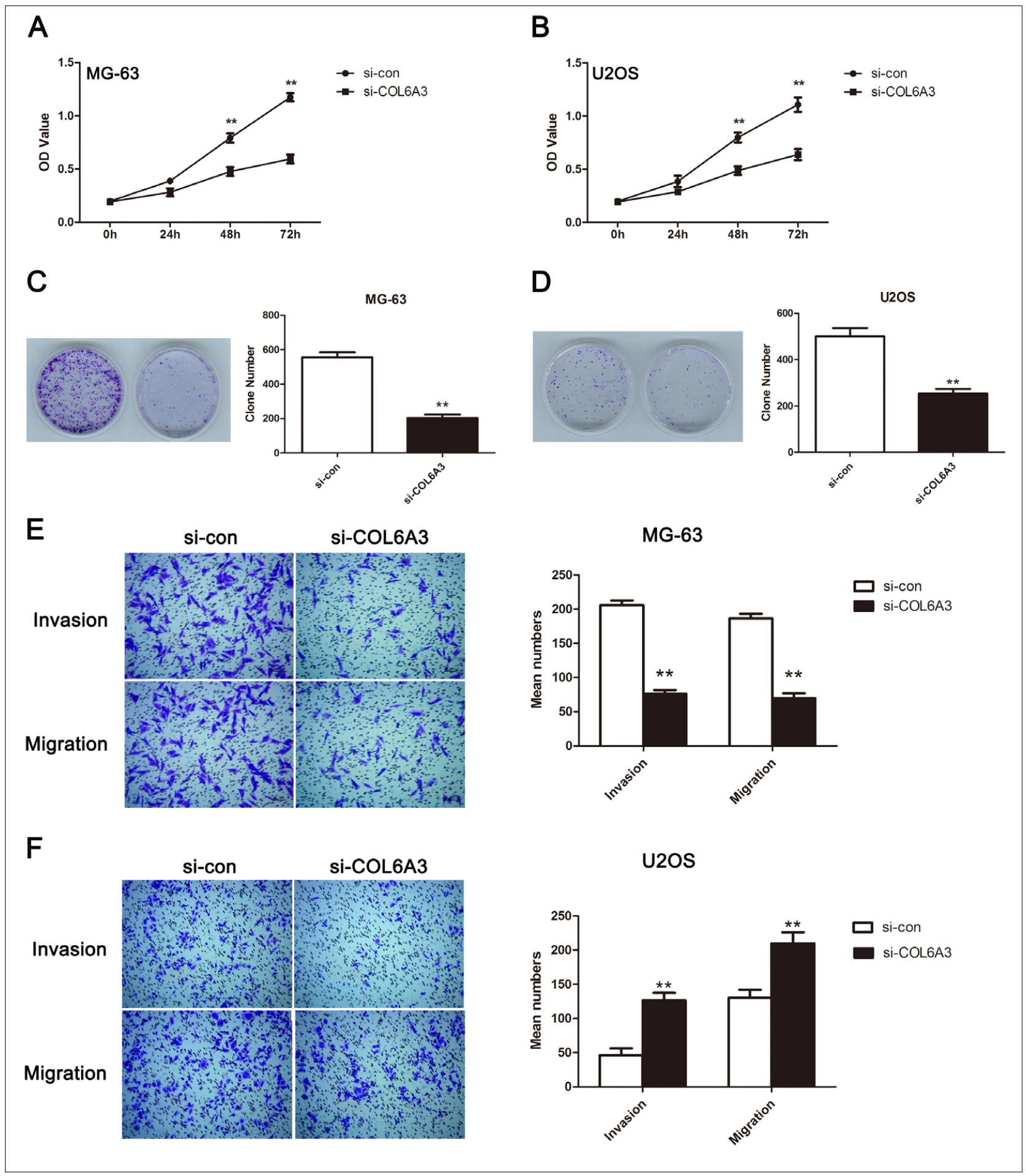

FIGURE 2. REDUCTION OF COL6A3 EXERTED NEGATIVE EFFECTS ON CELL MALIGNANT BEHAVIORS IN MG-63 AND U2OS CELLS. (A AND B) THE CELL VIABILITY OF OSTEOSARCOMA CELLS TRANSFECTED WITH SI-COL6A3 WAS HINDERED USING CCK-8 ASSAY, ${ }^{* *} P<0.01$. (C AND D), COLONY ACTIVITY WAS WEAKENED BY COLONY FORMATION ASSAY AFTER KNOCKDOWN OF COL6A3, ${ }^{* *} P<0.01$. (E AND F) SILENCING THE COL6A3 HAD NEGATIVE IMPACTS ON MIGRATORY AND INVASIVE ABILITIES IN OSTEOSARCOMA, ${ }^{* \star} \mathrm{P}<0.01$.

expression. Subsequently, we detected the COL6A3 expression in three osteosarcoma cell lines (U2OS, HOS, and MG-63) and one normal human cell line hFOB1.19. Compared with the normal human cell line hFOB1.19, COL6A3 showed diverse expression patterns (Fig.1C, $\mathrm{P}<0.001$ ). Based on the expression level of COL6A3, we selected the two cell lines U2OS and MG-63 for future experiments. 


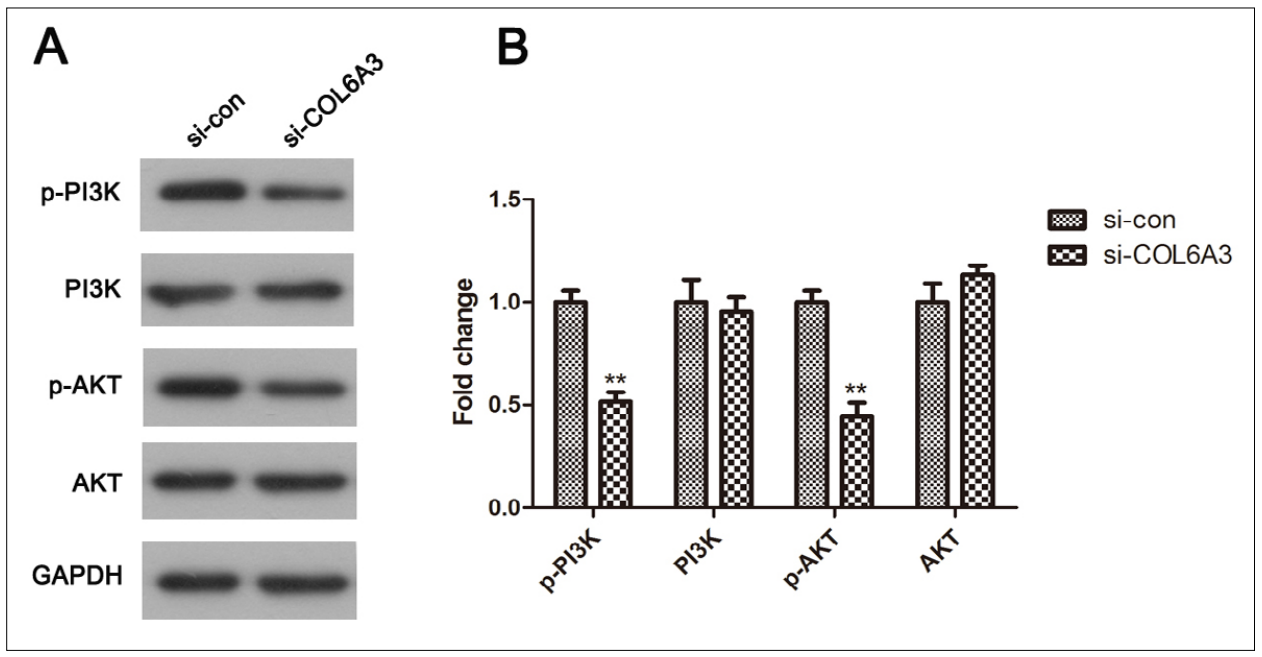

FIGURE 3. COL6A3 KNOCKDOWN WAS ASSOCIATED WITH THE INACTIVATION OF THE PI3K/AKT SIGNALING PATHWAY.
COL6A3 expression was down-regulated in U2OS and MG-63 cells

To verify the following results correctly, we used siRNA technology to knockdown the expression of COL6A3 and evaluate the silencing efficiency by qRTPCR and western blot. As shown in Figure 1A and 2C, we observed that the interference of si-COL6A3 successfully decreased COL6A3 mRNA expression by qRT-PCR $(\mathrm{P}<0.05)$. Consistently, the western blotting results indicated that the COL6A3 protein expression level was inhibited in U2OS and MG-63 cells (Figure $1 \mathrm{~B}$ and 2D, $\mathrm{P}<0.05)$.

\section{Depletion of COL6A3 inhibited cell} proliferation, invasion, and migration in

\section{U2OS and MG-63}

Next, we assessed the effects of knockdown COL6A3 on cell aggressive behaviors. The results of the CCK- 8 assay revealed that the down-regulation of COL6A3 suppressed cell growth and an evident difference was observed at $48 \mathrm{~h}, 72 \mathrm{~h}$ between the si-COL6A3 group and si-con group in both MG-63 and $\mathrm{U} 2 \mathrm{OS}$ cells (Figure2A and 2B, $\mathrm{P}<0.01$ ). In the same way, the clonogenic ability of MG-63 and U2OS cells transfected with si-COL6A3 also showed a downward trend (Figure2C and 2D, $\mathrm{P}<0.01$ ). To explore whether si-COL6A3 affected the capabilities of migration and invasion in osteosarcoma cells, we then performed a transwell assay. The representative images indicated that migratory and invasive cells in the si-COL6A3 group were fewer than in the si-con group in osteosarcoma cells (Figure2E and $2 \mathrm{~F}, \mathrm{P}<0.01)$.
COL6A3 knockdown was associated with the inactivation of PI3K/AKT signaling pathway

We determined the protein expression level of the PI3K/AKT pathway-related markers, including $\mathrm{p}$-PI3K/PI3K and p-AKT/AKT, in osteosarcoma cells. As illustrated in Figure 3A, U2OS and MG-63 cells transfected with si-COL6A3 exhibited a more down-regulated expression of p-PI3K/p-AKT than cells in the si-con group. The quantified analysis of gray value encouraged the above-mentioned results (Figure 3B, P < 0.01).

\section{DISCUSSION}

We found that COL6A3 was increased in osteosarcoma tissues and cells when compared with normal control. COL6 is expected to generate a flourishing condition for the development of tumors by cooperating with the extracellular matrix (ECM) rebuilding. Cell anchoring has also been proven to correlate with $\mathrm{COL6}^{8-10}$. Considering the mentioned researches, we predicted that COL6A3, which acts as a component of COL6, would participate in tumor progression. Furthermore, its function has been evaluated in several cancers, such as pancreatic ${ }^{11}$, giant cell tumors ${ }^{12}$, and prostate $^{13}$. However, the effects of COL6A3 on osteosarcoma are still unclear. Hence, we performed this study to determine the biological potential of COL6A3 in osteosarcoma.

Next, we paid much attention to the molecular mechanism of how COL6A3 manipulates cell activities. It is well-known that the PI3K/AKT signaling pathway is one of the most important cancer-related 
pathways ${ }^{14}$. The activation of the PI3K/AKT signaling pathway is recognized to exert a pivotal role in cell malignant motility in cancer progress ${ }^{\text {ion15,16. }}$. In addition to that, COL6A3 has been reported to be involved in the progression of gastric cancer by regulating the PI3K/AKT signaling pathway ${ }^{17}$. The same function has also been indicated in esophageal cancer in the Chinese population ${ }^{18}$. Therefore, we conducted western blotting to demonstrate the expression level of the PI3K/AKT signaling pathway-related markers after knockdown of the COL6A3.

\section{CONCLUSION}

These findings propose a new perspective in the diagnosis and treatment of osteosarcoma, manifesting important clinical implications against osteosarcoma.

\section{Conflicts of interest}

They have no conflicts of interest.

\section{Author Contributions}

Conceptualization, Jia Sun; formal analysis, Ze-Long Song; writing (original draft preparation), Hong-Li Guo; writing (review and editing), Gang Chen; supervision, Xi-Hai Gao; funding acquisition, Yu-Xia Han

\section{RESUMO}

OBJETIVO: Neste estudo, investigamos a função do COL6A3 na mobilidade celular e na via PIBK/AKT em osteossarcomas.

METODOLOGIA: A expressão relativa do COL6A3 foi obtida a partir de dados GEO em tecidos de osteossarcoma. O RNA de interferência (siRNA) foi utilizado para reduzir a expressão do COL6A3 nas células, e o teste de contagem de células kit-8 (CCK-8) e a análise de formação de colônias foram realizados para examinar o potencial de proliferação celular. Além disso, o Transwell comprovou os efeitos do si-COL6A3 na invasão celular e migração em células de osteossarcoma. Para medir os níveis de expressão das proteínas e mRNAs, utilizamos transcriptase reversa quantitativa ( $q R T-P C R)$ e western blot.

RESULTADOS: O COL6A3 foi regulado nos tecidos e células do osteossarcoma quando comparado com o controle normal. A redução de COL6A3 reduziu a proliferação e a capacidades de formação de colônias em relação ao COL6A3 sem interferência. Do Mesmo modo, ao contrário do observado no grupo si-con, a invasão e migração celular foram inibidas no grupo si-COL6A3. Além disso, o resultado do western blot sugere que a via PI3K/AKT foi manipulada, medindo a expressão proteica dos marcadores relacionados à PI3K/AKT, devido à inibição do COL6A3.

CONCLUSÃo: O COL6A3 desempenha um papel crucial na modulação de vários aspectos da progressão do osteossarcoma, o que pode representar um possivel tratamento eficaz para a doença.

PALAVRAS-CHAVE: Osteossarcoma. Neoplasias de tecido ósseo. Terapia de alvo molecular. Colágeno tipo VI.

\section{REFERENCES}

1. Gao Y, Qu Y, Zhou Q, Ma Y. SIRT6 inhibits proliferation and invasion in osteosarcoma cells by targeting N-cadherin. Oncol Lett. 2019;17(1):1237-44.

2. Ottaviani G, Jaffe N. The epidemiology of osteosarcoma. Cancer Treat Res. 2009;152:3-13

3. Baudino TA. Targeted cancer therapy: the next generation of cancer treatment. Curr Drug Discov Technol. 2015;12(1):3-20.

4. Zhou W, Hao M, Du X, Chen K, Wang G, Yang I. Advances in targeted therapy for osteosarcoma. Discov Med. 2014;17(96):301-7.

5. Lee JH, Shin HY, Park HJ, Kim SH, Kim SM, Choi YC. Clinical, pathologic, and genetic features of collagen VI-related myopathy in Korea. J Clin Neurol. 2017;13(4):331-9.

6. Bernardi P, Bonaldo P. Dysfunction of mitochondria and sarcoplasmic reticulum in the pathogenesis of collagen VI muscular dystrophies. Ann N Y Acad Sci. 2008;1147:303-11.

7. Merlini L, Bernardi P. Therapy of collagen VI-related myopathies (Bethlem and Ullrich). Neurotherapeutics. 2008;5(4):613-8.

8. Lohi J, Leivo I, Oivula J, Lehto VP, Virtanen I. Extracellular matrix in renal cell carcinomas. Histol Histopathol. 1998;13(3):785-96.

9. Sethi T, Rintoul RC, Moore SM, MacKinnon AC, Salter D, Choo C, et al. Extracellular matrix proteins protect small cell lung cancer cells against apoptosis: a mechanism for small cell lung cancer growth and drug resistance in vivo. Nat Med. 1999;5(6):662-8

10. Sherman-Baust CA, Weeraratna AT, Rangel LB, Pizer ES, Cho KR, Schwartz $D R$, et al. Remodeling of the extracellular matrix through overexpression of collagen VI contributes to cisplatin resistance in ovarian cancer cells. Cancer Cell. 2003;3(4):377-86.

11. Arafat H, Lazar M, Salem K, Chipitsyna G, Gong Q, Pan TC, et al. Tumor-specific expression and alternative splicing of the COL6A3 gene in pancreatic cancer. Surgery. 2011;150(2): 306-15.

12. Möller E, Mandahl N, Mertens F, Panagopoulos I. Molecular identification of COL6A3-CSF1 fusion transcripts in tenosynovial giant cell tumors. Genes Chromosomes Cancer. 2008;47(1):21-5.

13. Thorsen K, Sørensen KD, Brems-Eskildsen AS, Modin C, Gaustadnes M, Hein AM, et al. Alternative splicing in colon, bladder, and prostate cancer identified by exon array analysis. Mol Cell Proteomics. 2008;7(7):1214-24.

14. Zhang J, Yu XH, Yan YG, Wang C, Wang WJ. PI3K/Akt signaling in osteosarcoma. Clin Chim Acta. 2015;444:182-92.

15. Polivka J, Janku F. Molecular targets for cancer therapy in the PI3K/AKT/ mTOR pathway. Pharmacol Ther. 2014;142(2):164-75.

16. Porta C, Paglino C, Mosca A. Targeting PI3K/Akt/mTOR signaling in cancer. Front Oncol. 2014;4:64.

17. Ao R, Guan L, Wang Y, Wang JN. Silencing of COL1A2, COL6A3, and THBS2 inhibits gastric cancer cell proliferation, migration, and invasion while promoting apoptosis through the PI3k-Akt signaling pathway. J Cell Biochem. 2018;119(6):4420-34.

18. Li Y, Sun Y, Yang Q, Wu J, Xiong Z, Li S. Variants in COL6A3 gene influence susceptibility to esophageal cancer in the Chinese population. Cancer Genet. 2019;238:23-30. 